\title{
ANALISA TINGKAT BAHAYA EROSI PADASUB DAS LESTI KABUPATEN MALANG MENGGUNAKAN SISTEM INFORMASI GEOGRAFIS
}

\author{
Ernawan Setyono $^{1}$ \& Bangkit Prasetyo ${ }^{2}$ \\ ${ }^{1 \& 2}$ Fakultas Teknik Jurusan Teknik Sipil Universitas Muhammadiyah Malang \\ Alamat Korespondensi : Jl. Raya Tlogomas, No.246 Malang \\ email :ernawan@umm.ac.id, Telp03419591639
}

\begin{abstract}
Sub DAS Lesti is a part of Brantas watershed that located at upstream section and a sub DAS priority. That has $61.491,02$ ha of water catchment areas. Hydrological processes that occur in a watershed is closely related to erosion. The alteration of land use and watershed management is one of the factors causing soil damage, accelerate the erosion rate, and cause erosion. Based on the condition of that case, this study analyzes about how much the erosion rate, the amount of erosion, and to estimate the level of erosion that will occur.

MUSLE method is one of the methods used to determine the magnitude of the erosion rate, that use an approach of runoff factor. Geographic Information Systems (GIS) used for the management and data processing. Geographic Information Systems is a spatially information technology that generate digital data which can gives the area characteristics, and illustrates the potential of soil damage.

The level of erosion hazard on Sub DAS Lesti for weight categories reach $31.421 \%$ of the area, while another erosion rate is Medium 24.146\%, Lightweight 22.151\%, Very Heavy $16.123 \%$, and Very Light $6.159 \%$.
\end{abstract}

\section{PENDAHULUAN}

Daerah Aliran Sungai (DAS) adalah suatu wilayah daratan yang secara topografik dibatasi oleh punggung-punggung gunung yang menampung dan menyimpan air hujan untuk kemudian menyalurkannya ke laut melalui sungai utama. Dimana wilayah daratan tersebut dinamakan daerah tangkapan air (DTA atau catchment area) yang merupakan ekosistem dengan unsur utamanya terdiri atas sumberdaya alam (tanah, air, dan vegetasi) dan sumberdaya manusia sebagai pemanfaat sumberdaya alam (Chay Asdak, 2002:4).

Pengelolaan DAS merupakan kegiatan yang bersifat manipulasi sumberdaya alam dan manusia yang terdapat di DAS untuk memperoleh manfaat tanpa menyebabkan terjadinya kerusakan sumber daya air dan tanah. Pengelolaan DAS mempunyai arti sebagai pengelolaan dan alokasi sumberdaya alam di daerah aliran sungai, dimana selain usaha pencegahan banjir, pencegahan erosi juga merupakan salah satu implementasinya.
Sub DAS Lesti merupakan bagian dari DAS Brantas yang bermuara ke waduk Sengguruh. Secara administratif Lokasi studi yaitu Sub DAS Lesti terletak pada Kabupaten Malang, di bagian hulu sebelah timur Kabupaten Malang yang memberikan kontribusi debit air sungai yang besar ke bagian hilir Kabupaten Malang, tepatnya di waduk Sengguruh dan bendungan Sutami. Tingginya tingkat erosi yang terjadi di wilayah Sub DAS Lesti disebabkan oleh bentuk topografinya sebagian besar berombak-bergelombang dan berbukitbergunung dengan kemiringan lereng 8-45 \%, dan besarnya Intensitas curah hujan yang tinggi di wilayah Sub DAS Lesti. Berdasarkan pada kondisi yang terjadi, maka studi ini menganalisa tentang seberapa besar laju erosi, besaran erosi, dan tingkat bahaya erosi yang akan terjadi.

Adapun tujuan dari studi ini adalah :

- Untuk mengetahui berapa besarnya laju erosi pada DAS Lesti.

- Untuk mengetahui tingkat tingkat bahaya erosi pada DAS Lesti. 
- Pemanfaatan sistem informasi geografi untuk penyelesaian masalah-masalah sumberdaya air.

- Sedangkan manfaat kajian dari studi ini dapat diambil langkah-langkah dalam menentukan ARLKT (Arahan Rehabilitasi Lahan dan Konservasi Tanah) dan mengetahui tentang pemanfaatan SIG dalam usaha perencanaan dan pengelolaan DAS yang berkelanjutan.

\section{Analisa Hidrologi Daerah Kajian}

Analisa hidrologi pada dasarnya merupakan proses pengolahan data curah hujan, data luas dan bentuk daerah pengaliran (catchment area), data kemiringan lahan atau beda tinggi, dan data tata guna lahan yang kesemuanya memiliki arahan untuk mengetahui besarnya curah hujan maksimum, koefisien pengaliran, waktu konsentrasi, intensitas curah hujan, dan debit banjir rencana. Adapun langkahlangkah dalam analisa hidrologi ini meliputi :

- Uji Konsistensi Data

- Curah Hujan Rerata Daerah (Areal Rainfall)

- Analisa Curah Hujan Rancangan

\section{Debit Banjir Rancangan Metode Rasional Modifikasi}

Metode rasional adalah metode untuk menghitung debit banjir maksimum dari curah hujan. Metode ini dapat menggambarkan hubungan antara debit limpasan dengan besar curah hujan secara praktis berlaku untuk luas sub DAS hingga 300 ha. Rumus yang digunakan adalah:

$$
Q=0,00278 \text {.Cs. C.I.A }
$$

Dengan :

$\mathrm{Q}=$ Debit puncak (m3/dt)

I = Intensitas hujan rata-rata $(\mathrm{mm} / \mathrm{jam})$

A = Daerah tangkapan (ha)

$\mathrm{C}=$ Koefisien pengaliran

Cs = Koefisien tampungan

\section{Pendugaan Laju Erosi Metode MUSLE (Modified Universal Soil Loss Equation)}

Untuk memperkirakan besarnya erosi dalam studi ini menggunakan metode MUSLE (Modified Universal Soil Loss Equation) atau MPUKT
(Modifikasi Persamaan Umum Kehilangan Tanah). Persamaan MUSLE menurut Williams (1975) adalah sebagai berikut (Utomo, 1994 : 154) :

$A=R w \cdot K \cdot L \cdot S \cdot C \cdot P$

Dimana+ :

$\mathrm{A}=$ Besarnya kehilangan tanah per satuan luas lahan (ton/ha)

$\mathrm{Rw}=$ Indeks erosivitas limpasan permukaan (MJ.cm.ha-1.jam-1.tahun-1)

$\mathrm{K}$ = Indeks erodibilitas tanah (Ton hajam.ha-1.MJ1.cm-1)

$\mathrm{L}=$ Faktor panjang lereng

$\mathrm{S}=$ Faktor kemiringan lereng

$\mathrm{C}=$ Faktor pengelolaan tanaman

$\mathrm{P}=$ Faktor pengolahan tanah

Pendugaan Tingkat Bahaya Erosi (TBE)

Tingkat Bahaya Erosi juga dapat diperhitungkan dari jumlah tanah yang hilang maksimum dalam ton/ ha/thn pada setiap unit lahan, kemudian diklasifikasikan erosinya sesuai dengan ketentuan yang telah ditetapkan, dikombinasi dengan solum tanah maka akan diperoleh kelas tingkat bahaya erosi. Perkiraan erosi tahunan rata-rata dan solum (kedalaman) tanah dipertimbangkan untuk menentukan Tingkat Bahaya Erosi (TBE) untuk setiap 'satuan lahan' .

Tabel 1 Kelas Tingkat Bahaya Erosi

\begin{tabular}{lccccc}
\hline & \multicolumn{5}{c}{ Kelas Erosi } \\
\cline { 2 - 6 } Solum Tanah & I & II & III & IV & V \\
\cline { 2 - 6 } & \multicolumn{5}{c}{ Erosi (ton/ha/tahun) } \\
\cline { 2 - 6 } & $\mathbf{1 5}$ & $\mathbf{1 5 -}$ & $\mathbf{6 0}$ & $\mathbf{1 8 0}$ & \\
& $\mathbf{1 5}$ & & $\mathbf{1 8 0}$ & $\mathbf{4 8 0}$ & $>\mathbf{4 8 0}$ \\
\hline $\begin{array}{l}\text { Dalam (> 90) } \\
\text { Sedang (60- }\end{array}$ & SR & R & S & B & SB \\
90) & R & S & B & SB & SB \\
$\begin{array}{l}\text { Dangkal (30- } \\
\text { 60) }\end{array}$ & S & B & SB & SB & SB \\
$\begin{array}{l}\text { Sangat } \\
\text { Dangkal (< } \\
\text { 30) }\end{array}$ & B & SB & SB & SB & SB \\
\hline
\end{tabular}

Sumber : Utomo, WH, 1994;59 
Keterangan :

SR = Sangat Ringan,

$\mathrm{R}$ = Ringan,

$\mathrm{S} \quad=$ Sedang

$\mathrm{B}=$ Berat,

$\mathrm{SB}=$ Sangat Berat

\section{METODE PENELITIAN}

\section{Metode Pengumpulan Data}

Data-data yang diperlukan untuk menyelesaikan studi ini adalah sebagai berikut: Data curah hujan tahun 2002-2011, peta batas DAS dan jaringan sungai, peta jenis tanah, tekstur tanah dan struktur tanah, peta solum tanah, peta stasiun penakar hujan, peta tata guna lahan diperoleh dari Balai Besar Wilayah Sungai Brantas, sedangkan peta kontur topografi Rupa Bumi Indonesia (RBI) diperoleh dari BAKOSURTANAL. Semua data diperoleh dalam bentuk digital.

\section{Langkah-langkah Studi}

Adapun langkah-langkah dalam menyelesaikan kegiatan penelitian secara berturutan dilakukan sebagai berikut :

1. Analisa hidrologi

2. Analisa debit limpasan permukaan

3. Analisa Laju Erosi

4. Analisa Tingkat Bahaya Erosi

Dalam menganalisa tata guna lahan eksisting pada Sub DAS Lesti, digunakan Sistem Informasi Geografis yang bertujuan untuk menentukan besaran laju erosi yang terjadi terhadap kedalaman solum tanah.

\section{HASIL DAN PEMBAHASAN Analisa Hidrologi}

Analisa hidrologi diperlukan untuk mengetahui sebaran nilai dari intensitas hujan harian rata-rata yang terjadi pada sub DAS Lesti. Dengan mengetahui sebaran intensitas hujan harian rata-rata menurut luas daerah pengaruh yang dibatasi oleh polygon thiessen setiap stasiun hujan. Adapun stasiun pengamatan hujan yang digunakan untuk mengambil data hujan dari Sub DAS Lesti meliputi 5 stasiun hujan dengan rentang waktu selama 10 tahun

Tabel 2 Curah Hujan Tahunan

\begin{tabular}{cccccc}
\hline Tahun & \multicolumn{5}{c}{ Curah Hujan Tahunan $(\mathrm{mm})$} \\
\cline { 2 - 6 } & $\begin{array}{c}\text { Sta. } \\
\text { Poncokusumo } \\
(\mathrm{mm})\end{array}$ & $\begin{array}{c}\text { Sta. } \\
\text { Pagak } \\
(\mathrm{mm})\end{array}$ & $\begin{array}{c}\text { Sta. } \\
\text { Turen } \\
(\mathrm{mm})\end{array}$ & $\begin{array}{c}\text { Sta. } \\
\text { Bululawang } \\
(\mathrm{mm})\end{array}$ & $\begin{array}{c}\text { Sta. } \\
\text { Dampit } \\
(\mathrm{mm})\end{array}$ \\
\hline 2011 & 2.611 & 1.945 & 2.539 & 2.267 & 2.385 \\
2010 & 2.206 & 1.371 & 1.691 & 1.912 & 1.662 \\
2009 & 2.168 & 1.573 & 2.225 & 1.478 & 2.510 \\
2008 & 2.735 & 1.696 & 1.996 & 1.819 & 1.850 \\
2007 & 2.453 & 1.468 & 1.691 & 2.112 & 1.921 \\
2006 & 2.694 & 1.392 & 2.023 & 2.194 & 1.830 \\
2005 & 2.848 & 1.581 & 1.857 & 2.101 & 1.763 \\
2004 & 3.554 & 2.227 & 2.079 & 2.243 & 1.924 \\
2003 & 2.603 & 1.542 & 2.240 & 2.335 & 1.819 \\
2002 & 3.369 & 2.675 & 3.786 & 2.557 & 2.954 \\
\hline
\end{tabular}

Sumber : Analisa dan Perhitungan

Tabel 3 Curah Hujan Maksimum Tahunan

\begin{tabular}{cccccc}
\hline & \multicolumn{5}{c}{ Curah Hujan Tahunan $(\mathrm{mm})$} \\
\cline { 2 - 6 } Tahun & $\begin{array}{c}\text { Sta. } \\
\text { Ponco } \\
\text { kusumo } \\
(\mathrm{mm})\end{array}$ & $\begin{array}{c}\text { Sta. } \\
\text { Pagak } \\
(\mathrm{mm})\end{array}$ & $\begin{array}{c}\text { Sta. Turen } \\
(\mathrm{mm})\end{array}$ & $\begin{array}{c}\text { Sta. Bulu } \\
\text { lawang } \\
(\mathrm{mm})\end{array}$ & $\begin{array}{c}\text { Sta. } \\
\text { Dampit } \\
(\mathrm{mm})\end{array}$ \\
\hline 2011 & 151 & 117 & 197 & 130 & 225 \\
2010 & 56 & 69 & 108 & 75 & 106 \\
\hline
\end{tabular}




\begin{tabular}{cccccc}
\hline 2009 & 56 & 133 & 164 & 65 & 145 \\
2008 & 86 & 175 & 110 & 87 & 167 \\
2007 & 62 & 115 & 96 & 99 & 98 \\
2006 & 91 & 163 & 140 & 110 & 149 \\
2005 & 72 & 85 & 105 & 90 & 84 \\
2004 & 71 & 70 & 71 & 82 & 106 \\
2003 & 83 & 95 & 126 & 101 & 149 \\
2002 & 74 & 80 & 113 & 72 & 124 \\
\hline
\end{tabular}

Sumber : Analisa dan Perhitungan

\section{Curah Hujan Rerata Daerah}

Daerah tinjauan DAS Lesti memiliki luasan 61941.300 ha dan termasuk DAS dengan luasan sedang $(500 \mathrm{~s} / \mathrm{d} 5000 \mathrm{~km} 2)$ sehingga dapat menggunakan metode Thiessen. Untuk menentukan curah hujan rerata daerah maka digunakanlah metode Thiessen.

Tabel 4 Perhitungan Koefisien Thiessen dan Curah Hujan Rerata Daerah

\begin{tabular}{cccccccr}
\hline No & Tahun & $\begin{array}{c}\text { Sta. } \\
\text { Ponco } \\
\text { Kusumo } \\
(\mathbf{m m})\end{array}$ & $\begin{array}{c}\text { Sta. Pagak } \\
(\mathbf{m m})\end{array}$ & $\begin{array}{c}\text { Sta Turen } \\
(\mathbf{m m})\end{array}$ & $\begin{array}{c}\text { Sta. Bulu } \\
\text { lawang } \\
(\mathbf{m m})\end{array}$ & $\begin{array}{c}\text { Sta. } \\
\text { Dampit } \\
(\mathbf{m m})\end{array}$ & $\begin{array}{c}\text { CH Rata- } \\
\text { rata } \\
(\mathbf{m m})\end{array}$ \\
\cline { 2 - 6 } & $\mathbf{0 . 2 2 2}$ & $\mathbf{0 . 1 4 1}$ & $\mathbf{0 . 2 4 9}$ & $\mathbf{0 . 0 0 9}$ & $\mathbf{0 . 3 7 9}$ & \\
\hline 1 & 2002 & 16,423 & 11,292 & 28,086 & 0,662 & 47,018 & $\mathbf{1 0 3 , 4 8 1}$ \\
2 & 2003 & 18,420 & 13,409 & 31,318 & 0,929 & 56,497 & $\mathbf{1 2 0 , 5 7 3}$ \\
3 & 2004 & 15,757 & 9,880 & 17,647 & 0,754 & 40,192 & $\mathbf{8 4 , 2 3 1}$ \\
4 & 2005 & 15,979 & 11,997 & 26,098 & 0,828 & 31,851 & $\mathbf{8 6 , 7 5 3}$ \\
5 & 2006 & 20,196 & 23,007 & 34,797 & 1,011 & 56,497 & $\mathbf{1 3 5 , 5 0 8}$ \\
6 & 2007 & 13,760 & 16,232 & 23,861 & 0,910 & 37,159 & $\mathbf{9 1 , 9 2 2}$ \\
7 & 2008 & 19,086 & 24,700 & 27,341 & 0,800 & 63,322 & $\mathbf{1 3 5 , 2 4 9}$ \\
8 & 2009 & 12,428 & 18,772 & 40,763 & 0,598 & 54,980 & $\mathbf{1 2 7 , 5 4 1}$ \\
9 & 2010 & 12,428 & 9,739 & 26,844 & 0,690 & 40,192 & $\mathbf{8 9 , 8 9 3}$ \\
10 & 2011 & 33,512 & 16,514 & 48,965 & 1,195 & 85,314 & $\mathbf{1 8 5 , 5 0 0}$ \\
\hline
\end{tabular}

Sumber : Analisa dan Perhitungan

\section{Perhitungan Curah Hujan Rancangan}

Curah hujan rancangan adalah curah hujan terbesar yang mungkin terjadi di suatu daerah dengan peluang tertentu (CD. Soemarto,1995:125). Dalam perencanaan ini hujan rancangan dipilih cara $\log$ Pearson III.

Tabel 5 Curah Hujan Rancangan kala ulang 10 tahun

\begin{tabular}{|c|c|c|c|c|c|c|c|c|}
\hline \multirow{2}{*}{ No } & $\begin{array}{c}\text { Kala } \\
\text { Ulang } \\
\text { (Tr) }\end{array}$ & $\begin{array}{c}\mathrm{CH} \\
\text { rata- } \\
\text { rata }\end{array}$ & $\begin{array}{l}\text { Std } \\
\text { Dev. } \\
\text { (s) }\end{array}$ & $\begin{array}{c}\text { Kemencen } \\
\text { gan }\end{array}$ & Peluang & G & \multicolumn{2}{|c|}{$\begin{array}{c}\text { Curah Hujan } \\
\text { Rancangan (CHR) }\end{array}$} \\
\hline & (tahun) & $\begin{array}{l}(\log \\
x)\end{array}$ & $(\log )$ & (cs) & $(\%)$ & (tabel) & $\begin{array}{c}\log Q \\
=\log x+ \\
\text { G.s }\end{array}$ & $(\mathrm{mm})$ \\
\hline 1 & 10 & 2,051 & 0,111 & 0,640 & 10 & 1,330 & 2,199 & 158,170 \\
\hline
\end{tabular}

Sumber : Analisa dan Perhitungan 
Perhitungan Debit Limpasan Permukaan Metode Rasional Modifikasi

Debit limpasan permukaan dihitung berdasarkan

Sub-Sub DAS. Dimana pada Sub Das Lesti ini terdapat 67 Sub-sub DAS. Hasil dari perhitungan Debit Limpasan Dapat dilihat dalam Tabel berikut.

Tabel 6 Rekapitulasi Perhitungan Debit Limpasan Permukaan

\begin{tabular}{|c|c|c|c|c|c|c|c|c|}
\hline \multirow{2}{*}{$\begin{array}{l}\text { ID } \\
\text { Lesti }\end{array}$} & Luas Das & \multirow{2}{*}{$\begin{array}{c}\text { QP } \\
\left(\mathrm{m}^{3} / \mathrm{dt}\right. \\
\mathrm{k})\end{array}$} & \multirow[b]{2}{*}{$\begin{array}{c}\text { ID } \\
\text { Lesti }\end{array}$} & \multirow{2}{*}{$\begin{array}{c}\text { Luas Das } \\
(\mathbf{H a})\end{array}$} & \multirow{2}{*}{$\frac{\mathrm{QP}}{\left(\mathrm{m}^{3} / \mathrm{dtk}\right)}$} & \multirow{2}{*}{$\begin{array}{c}\text { ID } \\
\text { Les } \\
\text { ti }\end{array}$} & \multirow{2}{*}{$\begin{array}{c}\text { Luas Das } \\
\text { (Ha) }\end{array}$} & \multirow{2}{*}{$\frac{\mathrm{QP}}{\left(\mathrm{m}^{3} / \mathrm{dtk}\right)}$} \\
\hline & (Ha) & & & & & & & \\
\hline 1 & $2.249,000$ & 35,544 & 24 & $1.295,000$ & 12,266 & 46 & 86,000 & 2,603 \\
\hline 2 & 804,994 & 25,626 & 25 & 705,997 & 10,379 & 47 & 84,000 & 1,017 \\
\hline 3 & 565,997 & 18,797 & 26 & 610,998 & 13,363 & 48 & $1.145,000$ & 13,109 \\
\hline 4 & 507,997 & 18,947 & 27 & 536,998 & 13,689 & 49 & 46,000 & 2,187 \\
\hline 5 & 71,000 & 3,930 & 28 & 715,997 & 13,890 & 50 & 544,999 & 24,724 \\
\hline 6 & $3.157,000$ & 32,175 & 29 & $1.138,000$ & 18,966 & 51 & 387,999 & 8,991 \\
\hline 7 & $2.775,000$ & 37,771 & 30 & $2.306,000$ & 28,148 & 52 & $1.568,000$ & 24,670 \\
\hline 8 & 345,998 & 10,393 & 31 & 994,995 & 19,595 & 53 & $1.379,000$ & 31,794 \\
\hline 9 & 790,995 & 13,529 & 32 & 761,998 & 15,350 & 54 & 453,999 & 13,449 \\
\hline 10 & 872,994 & 17,044 & 33 & $1.244,000$ & 19,787 & 55 & $1.248,000$ & 22,261 \\
\hline 11 & 378,998 & 10,033 & 34 & 347,998 & 10,256 & 56 & 673,998 & 11,702 \\
\hline 12 & 758,997 & 14,018 & 35 & $1.075,000$ & 25,031 & 57 & $1.187,000$ & 19,243 \\
\hline 13 & 817,994 & 15,189 & 36 & $1.305,000$ & 27,388 & 58 & $1.715,000$ & 22,577 \\
\hline 14 & $1.316,000$ & 18,345 & 37 & 249,000 & 10,132 & 59 & $3.081,000$ & 37,067 \\
\hline 15 & 539,998 & 12,986 & 38 & $1.025,000$ & 14,827 & 60 & 959,998 & 23,126 \\
\hline 16 & 425,998 & 13,229 & 39 & 978,997 & 11,801 & 61 & 884,997 & 20,566 \\
\hline 17 & 588,997 & 14,692 & 40 & 359,999 & 8,555 & 62 & 887,995 & 21,281 \\
\hline 18 & 519,997 & 22,534 & 41 & 473,998 & 10,406 & 63 & 488,997 & 13,501 \\
\hline 19 & 124,999 & 3,994 & 42 & $1.797,000$ & 20,961 & 64 & $1.141,000$ & 34,745 \\
\hline 20 & 133,999 & 6,767 & 43 & 439,997 & 11,880 & 65 & $1.523,000$ & 33,428 \\
\hline 21 & 573,997 & 11,930 & 44 & 603,998 & 12,801 & 66 & 856,996 & 35,440 \\
\hline 22 & 527,997 & 13,935 & 45 & $1.896,000$ & 18,285 & 67 & 774,996 & 27,503 \\
\hline 23 & $1.281,000$ & 11,536 & & & & & & \\
\hline
\end{tabular}

Sumber : Analisa dan Perhitungan

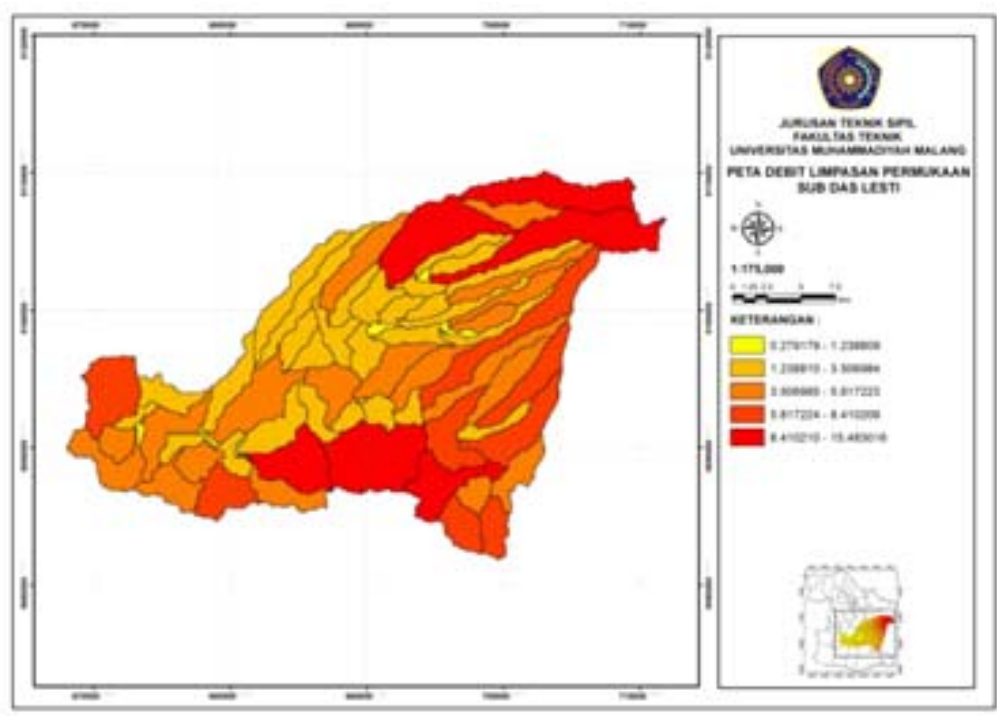

Gambar 1 Tampilan Debit Limpasan Permukaan 
Perhitungan Indeks Erosivitas Limpasan Permukaan (Rw)

Proses erosi selalu disertai dengan pengendapan dalam proses pengangkutan. Hasil endapan tersebut dipengaruhi oleh besar kecilnya limpasan permukaan . Pada studi ini, perhitungan Rw dihitung per Sub-Sub DAS Lesti.

Tabel 7 Rekapitulasi Perhitungan Indeks Erosivitas Limpasan Permukaan

\begin{tabular}{|c|c|c|c|c|c|c|}
\hline $\begin{array}{c}\text { Luas } \\
\text { Lahan } \\
(\mathbf{H a}) \\
\end{array}$ & $\begin{array}{c}\text { Panjang } \\
\text { Lahan } \\
(\mathrm{m})\end{array}$ & $\begin{array}{c}\text { RW } \\
\begin{array}{c}\text { 9,05.(Vo.Qp })^{0,56} \\
\left(\mathrm{~m}^{2} / \text { jam }\right)\end{array} \\
\end{array}$ & $\begin{array}{l}\text { Sub } \\
\text { DAS }\end{array}$ & $\begin{array}{c}\text { Luas } \\
\text { Lahan } \\
\text { (Ha) } \\
\end{array}$ & $\begin{array}{c}\text { Panjang Lahan } \\
\text { (m) }\end{array}$ & $\begin{array}{c}\text { RW } \\
\text { 9,05.(Vo.Qp) })^{0,56} \\
\left(\mathrm{~m}^{2} / \text { jam }\right)\end{array}$ \\
\hline $2.249,000$ & $15.473,511$ & 25191,881 & 35 & $1.075,000$ & $9.715,356$ & 18815,376 \\
\hline 804,994 & $8.443,970$ & 20974,650 & 36 & $1.305,000$ & $11.627,097$ & 19715,748 \\
\hline 565,997 & $7.415,055$ & 15406,665 & 37 & 249,000 & $3.093,974$ & 8020,942 \\
\hline 507,997 & $8.515,784$ & 15802,616 & 38 & $1.025,000$ & $6.439,281$ & 16012,771 \\
\hline 71,000 & $1.511,509$ & 6827,500 & 39 & 978,997 & $9.377,891$ & 11483,878 \\
\hline $3.157,000$ & $22.228,409$ & 22211,403 & 40 & 359,999 & $4.284,024$ & 11242,652 \\
\hline $2.775,000$ & $15.363,309$ & 25455,290 & 41 & 473,998 & $4.001,741$ & 12409,813 \\
\hline 345,998 & $5.024,143$ & 12273,441 & 42 & $1.797,000$ & $8.752,410$ & 12251,575 \\
\hline 790,995 & $12.266,061$ & 12832,578 & 43 & 439,997 & $6.977,031$ & 12393,235 \\
\hline 872,994 & $12.932,534$ & 14857,755 & 44 & 603,998 & $5.794,190$ & 15232,553 \\
\hline 378,998 & $4.806,856$ & 11530,957 & 45 & $1.896,000$ & $10.967,771$ & 15016,613 \\
\hline 758,997 & $6.367,341$ & 15822,632 & 46 & 86,000 & $2.569,491$ & 3527,681 \\
\hline 817,994 & $11.709,449$ & 14131,722 & 47 & 84,000 & $4.131,390$ & 2333,700 \\
\hline $1.316,000$ & $11.579,790$ & 18045,237 & 48 & $1.145,000$ & $9.414,980$ & 12127,415 \\
\hline 539,998 & $6.926,269$ & 14892,466 & 49 & 46,000 & $1.710,706$ & 3447,244 \\
\hline 425,998 & $4.485,560$ & 13803,564 & 50 & 544,999 & $3.704,259$ & 13265,310 \\
\hline 588,997 & $11.533,039$ & 14414,181 & 51 & 387,999 & $3.952,101$ & 7990,823 \\
\hline 519,997 & $5.816,216$ & 16851,918 & 52 & $1.568,000$ & $12.122,663$ & 18259,840 \\
\hline 124,999 & $2.328,291$ & 7432,465 & 53 & $1.379,000$ & $7.370,113$ & 21600,092 \\
\hline 133,999 & $3.111,738$ & 8501,797 & 54 & 453,999 & $3.859,265$ & 9613,639 \\
\hline 573,997 & $6.390,874$ & 12594,868 & 55 & $1.248,000$ & $7.497,760$ & 12787,995 \\
\hline 527,997 & $11.064,981$ & 13713,498 & 56 & 673,998 & $3.511,395$ & 9487,688 \\
\hline $1.281,000$ & $13.799,584$ & 13407,300 & 57 & $1.187,000$ & $12.336,502$ & 16493,794 \\
\hline $1.295,000$ & $15.942,044$ & 14374,235 & 58 & $1.715,000$ & $8.596,705$ & 18713,680 \\
\hline 705,997 & $7.546,361$ & 13296,263 & 59 & $3.081,000$ & $10.426,482$ & 24241,288 \\
\hline 610,998 & $6.077,243$ & 15529,115 & 60 & 959,998 & $6.260,568$ & 17724,490 \\
\hline 536,998 & $5.049,336$ & 16430,384 & 61 & 884,997 & $10.145,203$ & 18951,078 \\
\hline 715,997 & $5.070,067$ & 15225,357 & 62 & 887,995 & $6.998,570$ & 17038,265 \\
\hline $1.138,000$ & $10.107,507$ & 16182,823 & 63 & 488,997 & $3.565,692$ & 12689,785 \\
\hline $2.306,000$ & $20.047,669$ & 20675,720 & 64 & $1.141,000$ & $5.479,236$ & 22983,295 \\
\hline 994,995 & $9.136,730$ & 16848,032 & 65 & $1.523,000$ & $8.503,008$ & 23814,282 \\
\hline 761,998 & $6.339,198$ & 9610,994 & 66 & 856,996 & $5.380,114$ & 28035,064 \\
\hline $1.244,000$ & $14.767,742$ & 16194,564 & 67 & 774,996 & $5.570,390$ & 23589,940 \\
\hline 347,998 & $3.277,204$ & 12963,709 & & & & \\
\hline
\end{tabular}

Sumber : Hasil Analisa dan Perhitungan 


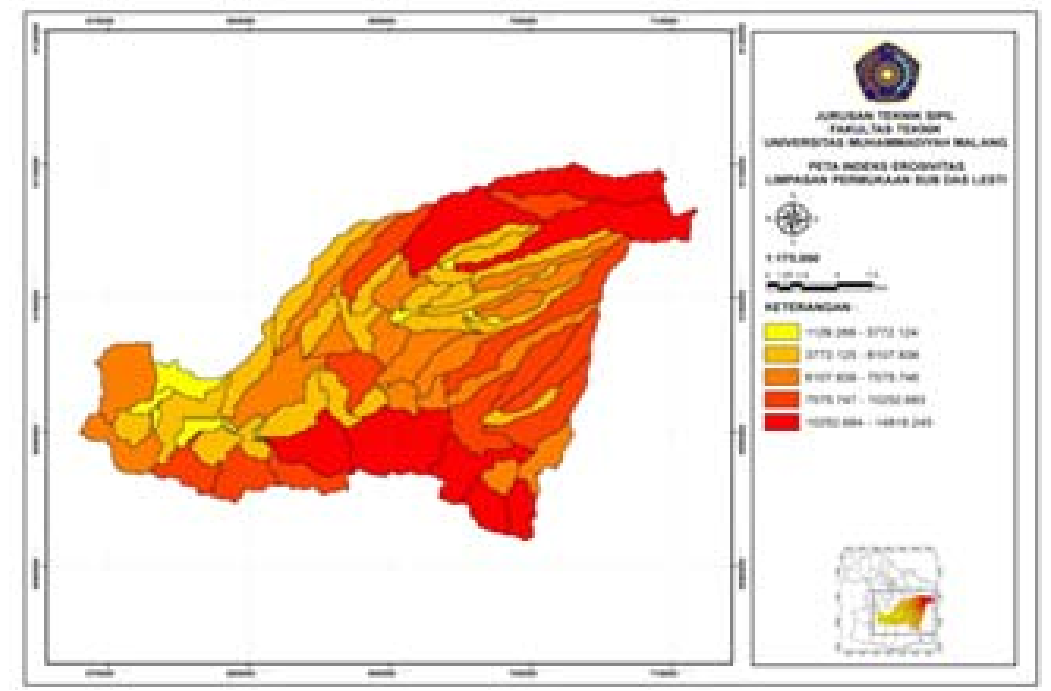

Gambar 2 Tampilan Indek Erosivitas Limpasan Permukaan

Perhitungan Laju Erosi Berdasarkan Metode MUSLE

Perhitungan duga erosi lahan eksisting ini dihitung per Sub DAS untuk tiap tataguna lahan dan jenis tanahnya. Untuk menentukan kelas bahaya erosi, dimana penentuannya berdasarkan atas erosi yang terjadi dan kedalaman solum tanah.

Tabel 8 Rekapitulasi Hasil Perhitungan Laju Erosi Berdasarkan Metode MUSLE

\begin{tabular}{rrrrrrr}
\hline $\begin{array}{c}\text { Luas Das } \\
(\mathbf{H a})\end{array}$ & $\begin{array}{c}\text { Erosi } \\
\text { (Ton/Ha/Thn) }\end{array}$ & $\begin{array}{c}\text { Erosi } \\
\text { (Ton/Thn) }\end{array}$ & $\begin{array}{c}\text { Lesti } \\
\text { Lo }\end{array}$ & \multicolumn{1}{c}{ Luas Das } & $\begin{array}{c}\text { Erosi } \\
\text { (Ton/Ha/Thn) }\end{array}$ & $\begin{array}{c}\text { Erosi } \\
\text { (Ton/Thn) }\end{array}$ \\
\hline $2.249,000$ & 1760,695 & 3959802,145 & 35 & $1.075,000$ & 129,620 & 139341,403 \\
804,994 & 1176,461 & 947044,295 & 36 & $1.305,000$ & 221,617 & 289210,632 \\
565,997 & 83,907 & 47490,901 & 37 & 249,000 & 74,678 & 18594,866 \\
507,997 & 142,631 & 72456,236 & 38 & $1.025,000$ & 136,872 & 140294,236 \\
71,000 & 9,693 & 688,168 & 39 & 978,997 & 204,648 & 200349,886 \\
$3.157,000$ & 1030,720 & 3253983,944 & 40 & 359,999 & 50,142 & 18051,223 \\
$2.775,000$ & 1078,560 & 2993003,425 & 41 & 473,998 & 32,054 & 15193,706 \\
345,998 & 63,346 & 21917,420 & 42 & $1.797,000$ & 99,098 & 178078,675 \\
790,995 & 206,852 & 163618,665 & 43 & 439,997 & 32,685 & 14381,288 \\
872,994 & 264,337 & 230764,833 & 44 & 603,998 & 111,286 & 67216,242 \\
378,998 & 55,429 & 21007,564 & 45 & $1.896,000$ & 203,426 & 385696,337 \\
758,997 & 125,674 & 95386,337 & 46 & 86,000 & 10,957 & 942,281 \\
817,994 & 305,936 & 250253,411 & 47 & 84,000 & 8,947 & 751,521 \\
$1.316,000$ & 611,563 & 804816,557 & 48 & $1.145,000$ & 84,247 & 96462,728 \\
539,998 & 209,936 & 113365,268 & 49 & 46,000 & 9,183 & 422,431 \\
425,998 & 46,083 & 19631,421 & 50 & 544,999 & 224,631 & 122423,722 \\
588,997 & 167,333 & 98558,657 & 51 & 387,999 & 82,947 & 32183,462 \\
519,997 & 114,407 & 59491,547 & 52 & $1.568,000$ & 52,973 & 81737,919 \\
124,999 & 10,290 & 1286,189 & 53 & $1.379,000$ & 58,827 & 39649,129 \\
133,999 & 22,291 & 2986,939 & 54 & 453,999 & 66,512 & 30196,647 \\
573,997 & 54,649 & 31368,324 & 55 & $1.248,000$ & 126,078 & 157345,614 \\
527,997 & 81,394 & 42975,748 & 56 & 673,998 & 107,839 & 72683,569 \\
$1.281,000$ & 183,066 & 234507,151 & 57 & $1.187,000$ & 764,705 & 907705,359 \\
\hline
\end{tabular}




\begin{tabular}{rrrrrrr}
\hline $1.295,000$ & 387,513 & 501829,594 & 58 & $1.715,000$ & 737,966 & 1265611,317 \\
705,997 & 196,726 & 138887,663 & 59 & $3.081,000$ & 402,685 & 1240671,109 \\
610,998 & 124,625 & 76145,802 & 60 & 959,998 & 665,386 & 638768,887 \\
536,998 & 95,145 & 51092,453 & 61 & 884,997 & 619,861 & 548575,184 \\
715,997 & 76,814 & 54998,574 & 62 & 887,995 & 55,372 & 49169,664 \\
$1.138,000$ & 75,407 & 85813,310 & 63 & 488,997 & 39,407 & 19270,124 \\
$2.306,000$ & 671,188 & 1547089,058 & 64 & $1.141,000$ & 526,651 & 600909,179 \\
994,995 & 66,607 & 66273,870 & 65 & $1.523,000$ & 281,976 & 429449,426 \\
761,998 & 39,301 & 29947,431 & 66 & 856,996 & 700,547 & 600365,717 \\
$1.244,000$ & 201,304 & 70053,329 & 67 & 774,996 & 526,607 & 408118,598 \\
347,998 & 16,361 & 5693,787 & & & &
\end{tabular}

Sumber : Hasil Analisa dan Perhitungan

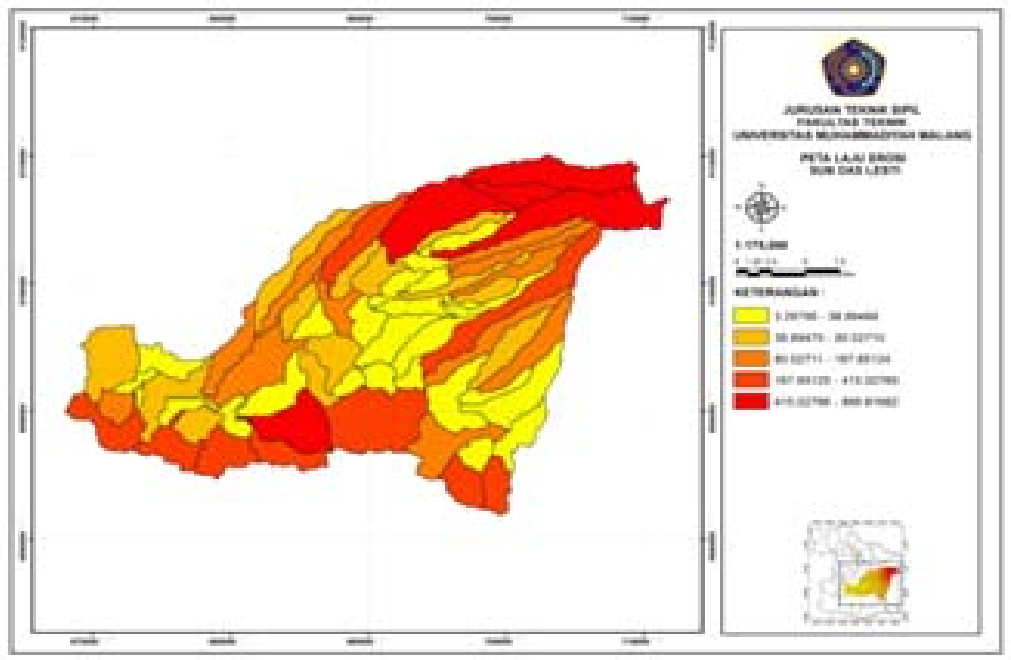

Gambar 3 Peta Laju Erosi Sub DAS Lesti

\section{Analisa Tingkat Bahaya Erosi (TBE)}

Analisa ini digunakan untuk mengetahui kondisi suatu lahan dengan melihat tingkat erosi yang terjadi dan dibandingkan dengan laju erosi yang diijinkan. Berdasarkan hasil analisa tingkat bahaya erosi dapat diketahui bahwa kondisi lahan pada DAS Lesti Kondisi Berat.

Tabel 9. Persentase Tingkat Bahaya Erosi Sub DAS Lesti

\begin{tabular}{lrc}
\hline $\begin{array}{c}\text { Tingkat Bahaya } \\
\text { Erosi }\end{array}$ & $\begin{array}{c}\text { Luas Lahan } \\
\text { (ha) }\end{array}$ & $\begin{array}{c}\text { Persentase } \\
\mathbf{( \% )}\end{array}$ \\
\hline Sangat Berat & $9.986,655$ & 16,123 \\
Berat & $19.462,352$ & 31,421 \\
Sedang & $14.956,309$ & 24,146 \\
Ringan & $13.720,558$ & 22,151 \\
Sangat Ringan & $3.815,146$ & 6,159 \\
\hline
\end{tabular}

Total 61.941,01972 100

Sumber : Hasil Analisa dan Perhitungan

Tabel 10 Tingkat Bahaya Erosi Sub DAS Lesti

\begin{tabular}{lccrccccr}
\hline & Luas & & \multicolumn{6}{c}{ Kelas Tingkat Bahaya Erosi (Ha) } \\
\cline { 5 - 9 } Sub & $\begin{array}{c}\text { Sub } \\
\text { Das }\end{array}$ & $\begin{array}{c}\text { Laju } \\
\text { Das }\end{array}$ & Erosi & SB & B & S & R & SR \\
& $($ Ha) & & & & & & & \\
\hline 1 & 2249 & 3959802,1 & 2249 & 0 & 0 & 0 & 0 \\
2 & 804,994 & 947044,3 & 804,994 & 0 & 0 & 0 & 0 \\
\hline
\end{tabular}




\begin{tabular}{|c|c|c|c|c|c|c|c|}
\hline 3 & 565,997 & 47490,901 & 0 & 224,861 & 341,135 & 0 & 0 \\
\hline 4 & 507,997 & 72456,236 & 0 & 0 & 507,997 & 0 & 0 \\
\hline 5 & 71 & 688,168 & 0 & 0 & 0 & 0 & 71 \\
\hline 6 & 3157 & 3253983,9 & 3084,311 & 0 & 0 & 0 & 0 \\
\hline 7 & 2775 & 2993003,4 & 2774,985 & 0 & 0 & 0 & 0 \\
\hline 8 & 345,998 & 21917,42 & 0 & 0 & 345,998 & 0 & 0 \\
\hline 9 & 790,995 & 163618,67 & 52,978 & 738,016 & 0 & 0 & 0 \\
\hline 10 & 872,994 & 230764,83 & 56,884 & 816,11 & 0 & 0 & 0 \\
\hline 11 & 378,998 & 21007,564 & 0 & 0 & 0 & 378,998 & 0 \\
\hline 12 & 758,997 & 95386,337 & 0 & 0 & 758,997 & 0 & 0 \\
\hline 13 & 817,994 & 250253,41 & 10,803 & 807,192 & 0 & 0 & 0 \\
\hline 14 & 1316 & 804816,56 & 1315,994 & 0 & 0 & 0 & 0 \\
\hline 15 & 539,998 & 113365,27 & 0 & 539,998 & 0 & 0 & 0 \\
\hline 16 & 425,998 & 19631,421 & 0 & 0 & 425,998 & 0 & 0 \\
\hline 17 & 588,997 & 98558,657 & 0 & 588,997 & 0 & 0 & 0 \\
\hline 18 & 519,997 & 59491,547 & 0 & 519,997 & 0 & 0 & 0 \\
\hline 19 & 124,999 & 1286,189 & 0 & 0 & 0 & 0 & 124,999 \\
\hline 20 & 133,999 & 2986,939 & 0 & 0 & 0 & 0 & 133,999 \\
\hline 21 & 573,997 & 31368,324 & 0 & 0 & 0 & 573,997 & 0 \\
\hline 22 & 527,997 & 42975,748 & 0 & 0 & 527,997 & 0 & 0 \\
\hline 23 & 1281 & 234507,15 & 1280,996 & 0 & 0 & 0 & 0 \\
\hline 24 & 1295 & 501829,59 & 0 & 1294,995 & 0 & 0 & 0 \\
\hline 25 & 705,997 & 138887,66 & 705,997 & 0 & 0 & 0 & 0 \\
\hline 26 & 610,998 & 76145,802 & 0 & 0 & 610,998 & 0 & 0 \\
\hline 27 & 536,998 & 51092,453 & 536,998 & 0 & 0 & 0 & 0 \\
\hline 28 & 715,997 & 54998,574 & 715,997 & 0 & 0 & 0 & 0 \\
\hline 29 & 1138 & 85813,31 & 0 & 0 & 1137,995 & 0 & 0 \\
\hline 30 & 2305 & 1547089,1 & 2304,638 & 0 & 0 & 0 & 0 \\
\hline 31 & 994,995 & 66273,87 & 0 & 0 & 994,995 & 0 & 0 \\
\hline 32 & 762 & 29947,431 & 0 & 0 & 0 & 761,998 & 0 \\
\hline 33 & 347,998 & 70053,329 & 1243,993 & 0 & 0 & 0 & 0 \\
\hline 34 & 348 & 5693,787 & 106,981 & 0 & 0 & 0 & 241,017 \\
\hline 35 & 1075 & 139341,4 & 0 & 0 & 1074,993 & 0 & 0 \\
\hline 36 & 1305 & 289210,63 & 0 & 1304,871 & & 0 & 0 \\
\hline 37 & 249 & 18594,866 & 224,943 & 0 & 24,057 & 0 & 0 \\
\hline 38 & 1025 & 140294,24 & 0 & 0 & 1024,996 & 0 & 0 \\
\hline 39 & 978,997 & 200349,89 & 978,997 & 0 & 0 & 0 & 0 \\
\hline 40 & 359,999 & 18051,223 & 0 & 0 & 0 & 359,999 & 0 \\
\hline 41 & 473,998 & 15193,706 & 0 & 0 & 0 & 473,998 & 0 \\
\hline 42 & 1797 & 178078,68 & 478,673 & 0 & 1318,324 & 0 & 0 \\
\hline 43 & 439,997 & 14381,288 & 0 & 0 & 0 & 439,997 & 0 \\
\hline 44 & 603,998 & 67216,242 & 0 & 0 & 603,998 & 0 & 0 \\
\hline 45 & 1896 & 385696,34 & 1895,995 & 0 & 0 & 0 & 0 \\
\hline 46 & 86 & 942,281 & 0 & 0 & 86 & 0 & 0 \\
\hline 47 & 84 & 751,521 & 0 & 0 & 0 & 0 & 84 \\
\hline 48 & 1145 & 96462,728 & 0 & 0 & 1144,997 & 0 & 0 \\
\hline 49 & 46 & 422,431 & 0 & 0 & 0 & 0 & 46 \\
\hline 50 & 544,999 & 122423,72 & 544,999 & 0 & 0 & 0 & 0 \\
\hline 51 & 387,999 & 32183,462 & 35,408 & 0 & 352,591 & 0 & 0 \\
\hline
\end{tabular}




\begin{tabular}{rrrrrrrr}
\hline 52 & 1543 & 81737,919 & 0 & 0 & 145,453 & 1397,703 & 0 \\
53 & 673,998 & 39649,129 & 770,045 & 608,948 & 0 & 0 & 0 \\
54 & 454 & 30196,647 & 0 & 345,505 & 108,494 & 0 & 0 \\
55 & 1248 & 157345,61 & 770,565 & 0 & 477,432 & 0 & 0 \\
56 & 673,998 & 72683,569 & 0 & 224,099 & 449,899 & 0 & 0 \\
57 & 1187 & 907705,36 & 1186,998 & 0 & 0 & 0 & 0 \\
58 & 1715 & 1265611,3 & 1714,995 & 0 & 0 & 0 & 0 \\
59 & 3081 & 1240671,1 & 1485,29 & 1595,698 & 0 & 0 & 0 \\
60 & 959,998 & 638768,89 & 959,998 & 0 & 0 & 0 & 0 \\
61 & 884,997 & 548575,18 & 884,997 & 0 & 0 & 0 & 0 \\
62 & 887,995 & 49169,664 & 0 & 676,514 & 180,972 & 0 & 0 \\
63 & 488,997 & 19270,124 & 0 & 488,997 & 0 & 0 & 0 \\
64 & 1141 & 600909,18 & 1140,997 & 0 & 0 & 0 & 0 \\
65 & 1523 & 429449,43 & 778,354 & 744,639 & 0 & 0 & 0 \\
66 & 856,996 & 600365,72 & 856,996 & 0 & 0 & 0 & 0 \\
67 & 774,996 & 408118,6 & 735,779 & 0 & 0 & 0 & 0 \\
\hline
\end{tabular}

Sumber : Hasil Analisa dan Perhitungan

Keterangan :

SR = Sangat Ringan

$\mathrm{R} \quad=$ Ringan

$$
\begin{array}{ll}
\mathrm{S} & =\text { Sedang } \\
\mathrm{B} & =\text { Berat } \\
\mathrm{SB} & =\text { Sangat Berat }
\end{array}
$$

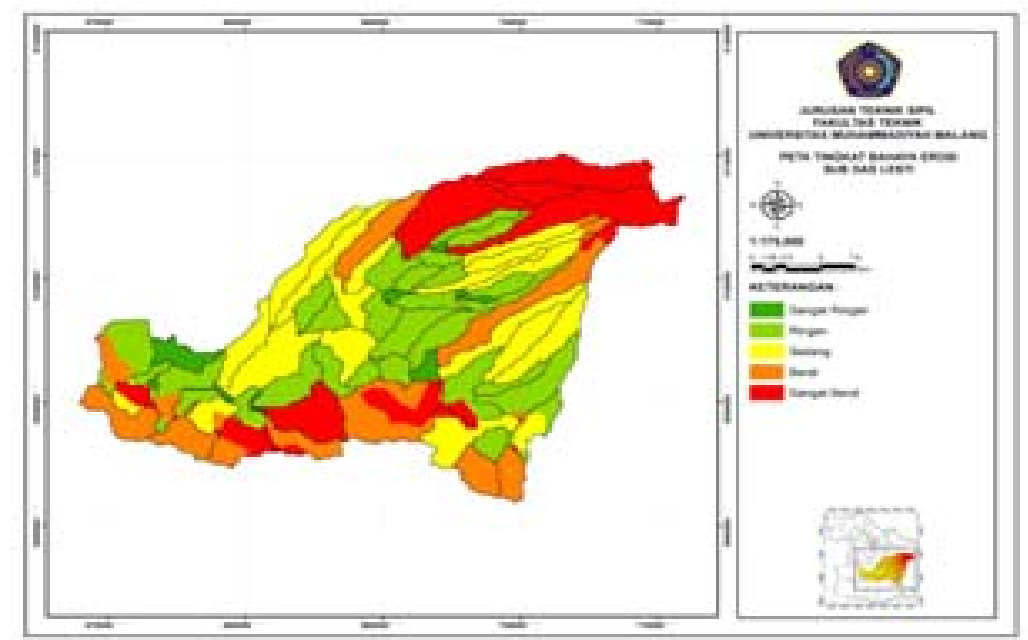

\begin{tabular}{|c|c|c|c|c|c|c|c|c|}
\hline \multirow{2}{*}{ No } & \multicolumn{2}{|c|}{ Lokasi } & \multirow{2}{*}{$\begin{array}{c}\text { Luas Desa } \\
\text { (Ha) }\end{array}$} & \multicolumn{5}{|c|}{ Tingkat Bahaya Erosi (Ha) } \\
\hline & Kecamatan & Desa & & SR & $\mathbf{R}$ & $\mathbf{S}$ & B & SB \\
\hline \multirow[t]{2}{*}{1} & Ampelgading & Ampelgading & 468,802 & 0 & 0 & 0 & 0 & 468,802 \\
\hline & & TOTAL & 468,802 & $\mathbf{0}$ & $\mathbf{0}$ & $\mathbf{0}$ & $\mathbf{0}$ & 468,802 \\
\hline \multirow[t]{6}{*}{2} & Bantur & Karangsari & 684,431 & 0 & 0 & 49,933 & 0 & 634,498 \\
\hline & & Rejosari & 670,289 & 0 & 0 & 52,303 & 13,663 & 604,32353 \\
\hline & & Rejoyoso & 425,629 & 0 & 38,317 & 36,06705 & 0 & 351,245 \\
\hline & & Pringgodani & 732,837 & 0 & 0 & 0 & 0 & 732,837 \\
\hline & & Wonokerto & 917,686 & 15,799 & 0 & 240,621 & 85,850 & 575,416 \\
\hline & & TOTAL & 3430,873 & 15,799 & 38,317 & 378,924 & 99,513 & 2898,320 \\
\hline \multirow[t]{3}{*}{3} & Bululawang & Kasri & 24,913 & 0 & 0 & 0 & 0 & 24,913 \\
\hline & & Sudimoro & 85,971 & 0 & 0 & 0 & 0 & 85,971 \\
\hline & & TOTAL & 110,883 & $\mathbf{0}$ & $\mathbf{0}$ & $\mathbf{0}$ & $\mathbf{0}$ & 110,883 \\
\hline
\end{tabular}

Gambar 4. Peta Tingkat Bahaya Erosi Per Sub DAS Lesti

Tabel 11 Tingkat Bahaya Erosi Per Desa 


\begin{tabular}{|c|c|c|c|c|c|c|c|c|}
\hline & \multirow[t]{13}{*}{ Dampit } & Amadanon & 890,704 & 0 & 4,646 & 37,915 & 0 & 848,143 \\
\hline \multirow{14}{*}{4} & & Bumirejo & 1151,774 & 0 & 134,203 & 128,798 & 505,835 & 382,938 \\
\hline & & Baturetno & 613,945 & 0 & 0 & 0 & 243,535 & 370,410 \\
\hline & & Dampit & 588,432 & 0 & 0 & 0 & 3,558 & 584,874 \\
\hline & & Jambangan & 664,370 & 5,214 & 0 & 481,264 & 0 & 177,892 \\
\hline & & & & 235,80 & & & & \\
\hline & & Pamotan & 1100,194 & 3 & 180,967 & 123,544 & 0 & 559,879 \\
\hline & & Pojok & 131,384 & 0 & 89,597 & 41,787 & 0 & 0 \\
\hline & & Majatengah & 457,967 & 0 & 147,315 & 0 & 0 & 310,652 \\
\hline & & Rembun & 333,774 & 0 & 155,575 & 0 & 0 & 178,199 \\
\hline & & Sumbersuko & 421,979 & 0 & 1,263 & 0 & 26,099 & 394,617 \\
\hline & & Srimulyo & 1495,188 & 0 & 0 & 0 & 622,765 & 872,423 \\
\hline & & Sukodono & 612,898 & 0 & 0 & 0 & 221,403 & 391,495 \\
\hline & & & & 241,01 & & & & \\
\hline & & TOTAL & 8462,609 & 7 & 713,566 & 813,308 & 1623,195 & $\mathbf{5 0 7 1 , 5 2 3}$ \\
\hline \multirow[t]{3}{*}{5} & Gedangan & Segaran & 1515,830 & 31,130 & 0 & 129,372 & 349,437 & 1005,890 \\
\hline & & Sumberejo & 1371,010 & 22,933 & 0 & 502,771 & 120,653 & 724,652 \\
\hline & & TOTAL & 2886,840 & 54,063 & $\mathbf{0}$ & 632,144 & 470,091 & 1730,542 \\
\hline \multirow[t]{19}{*}{6} & Gondanglegi & Balearjo & 238,261 & 0 & 215,133 & 7,463 & 0 & 15,665 \\
\hline & & Banjarjo & 28,817 & 0 & 0 & 0 & 0 & 28,817 \\
\hline & & Brongkal & 133,695 & 0 & 0 & 0 & 0 & 133,695 \\
\hline & & Clumprit & 857,963 & 60,137 & 0 & 427,490 & 0 & 370,336 \\
\hline & & Gondanglegi & & & & & & \\
\hline & & Wetan & 219,548 & 0 & 0 & 0 & 0 & 219,548 \\
\hline & & Gondanglegi & & & & & & \\
\hline & & Kulon & 104,547 & 0 & 0 & 0 & 0 & 104,547 \\
\hline & & Kademangan & 509,549 & 0 & 335,853 & 173,696 & 0 & 0 \\
\hline & & Kanigoro & 231,802 & 0 & 131,866 & 0 & 0 & 99,936 \\
\hline & & Pagelaran & 154,324 & 0 & 36,853 & 38,485 & 0 & 78,987 \\
\hline & & Putat Kidul & 94,699 & 0 & 0 & 0 & 0 & 94,699 \\
\hline & & Putat Lor & 164,044 & 0 & 0 & 0 & 0 & 164,044 \\
\hline & & Sepanjang & 1555,043 & 0 & 0 & 167,456 & 208,217 & 1179,370 \\
\hline & & Suwaru & 244,721 & 0 & 3,977 & 188,384 & 0 & 52,361 \\
\hline & & Sidorejo & 836,020 & 0 & 0 & 188,519 & 0 & 647,501 \\
\hline & & Sukorejo & 0,033 & 0 & 0 & 0,033 & 0 & 0 \\
\hline & & Urek-urek & 314,476 & 0 & 0 & 0 & 0 & 314,476 \\
\hline & & & & & & 1191,52 & & \\
\hline & & TOTAL & 5687,544 & 60,137 & 723,681 & 6 & 208,217 & 3503,982 \\
\hline \multirow[t]{4}{*}{7} & Kepanjen & Sengguruh & 30,551 & 0 & 0 & 30,551 & 0 & 0 \\
\hline & & Tegalsari & 8,802 & 0 & 0 & 8,802 & 0 & 0 \\
\hline & & Kemiri & 84,142 & 0 & 0 & 84,142 & 0 & 0 \\
\hline & & TOTAL & 123,496 & $\mathbf{0}$ & $\mathbf{0}$ & 123,496 & $\mathbf{0}$ & $\mathbf{0}$ \\
\hline \multirow[t]{6}{*}{8} & Pagak & Gampingan & 580,222 & 0 & 0 & 580,222 & 0 & 0 \\
\hline & & Pagak & 501,308 & 0 & 0 & 0,000 & 0 & 501,308 \\
\hline & & Sumberejo & 782,749 & 0 & 0 & 622,894 & 0 & 159,855 \\
\hline & & Sumberkerto & 93,567 & 0 & 0 & 0 & 0 & 93,567 \\
\hline & & & & & & 1203,11 & & \\
\hline & & TOTAL & 1957,847 & $\mathbf{0}$ & $\mathbf{0}$ & 6 & $\mathbf{0}$ & $\mathbf{7 5 4 , 7 3 1}$ \\
\hline \multirow[t]{4}{*}{9} & Poncokusumo & Dawuhan & 641,814 & 0 & 0 & 0 & 0 & 641,814 \\
\hline & & Jambesari & 0,328 & 0 & 0 & 0 & 0,328 & 0 \\
\hline & & Karanganyar & 91,969 & 0 & 0 & 0 & 2,695 & 89,274 \\
\hline & & Ngadireso & 165,357 & 0 & 0 & 0 & 0 & 165,357 \\
\hline
\end{tabular}




\begin{tabular}{|c|c|c|c|c|c|c|c|c|}
\hline \multirow[t]{12}{*}{11} & \multirow[t]{12}{*}{ Tirtoyudo } & Ampelgading & 902,095 & 0 & 481,789 & 11,079 & 409,227 & 0 \\
\hline & & Gunungsari & 492,230 & 0 & 452,372 & 0 & 39,858 & 0 \\
\hline & & Jogomulyan & 291,279 & 0 & 0 & 180,972 & 54,629 & 55,678 \\
\hline & & Kepatihan & 223,237 & 0 & 0 & 0 & 30,973 & 192,263 \\
\hline & & Sukorejo & 369,072 & 0 & 295,736 & 0 & 73,336 & 0 \\
\hline & & Sumbertangkil & 78,248 & 0 & 0 & 0 & 0 & 78,248 \\
\hline & & Tamankuncaran & 896,998 & 0 & 43,986 & $\begin{array}{r}412,397 \\
283,4280\end{array}$ & 440,615 & 0 \\
\hline & & Tamansatrian & 2801,339 & 0 & 0 & 1 & 351,846 & 2166,066 \\
\hline & & Tirtoyudo & 1107,080 & 0 & 292,347 & 0 & 646,395 & 168,338 \\
\hline & & Tlogosari & 206,491 & 0 & 132,622 & 0 & 73,869 & 0 \\
\hline & & Wonoagung & 796,484 & 0 & 0 & 426,915 & 73,817 & 295,752 \\
\hline & & TOTAL & 8164,553 & $\mathbf{0}$ & 1698,852 & 1314,792 & 2194,564 & 2956,345 \\
\hline \multirow[t]{19}{*}{12} & \multirow[t]{19}{*}{ Turen } & Gedongkulon & 169,095 & 0 & 0 & 169,095 & 0 & 0 \\
\hline & & Gedongwetan & 603,481 & 0 & 138,844 & 464,637 & 0 & 0 \\
\hline & & Jeru & 561,815 & 0 & 0 & 374,245 & 146,039 & 41,532 \\
\hline & & Kedok & 277,700 & 0 & 0 & 15,668 & 79,151 & 182,881 \\
\hline & & Kemulan & 148,021 & 0 & 0 & 119,036 & 0,000 & 28,985 \\
\hline & & Pagedangan & 772,570 & 0,660 & 7,692 & 61,585 & 18,674 & 683,959 \\
\hline & & Sananrejo & 513,642 & 77,259 & 30,337 & 136,716 & 103,824 & 165,505 \\
\hline & & Sanankerto & 1618,131 & 47,081 & $\begin{array}{r}458,5437 \\
8\end{array}$ & 1070,445 & 37,663 & 4,398 \\
\hline & & & & & & 180,4571 & & \\
\hline & & Sawahan & 180,457 & 0 & 0 & 4 & 0 & 0 \\
\hline & & Sedayu & 154,376 & 0 & 0 & 70,255 & 0 & 84,121 \\
\hline & & Talangsuko & 477,692 & 0 & 0 & 97,742 & 206,173 & 173,776 \\
\hline & & Talok & 885,799 & 0 & 0,590 & 646,128 & 0 & 239,081 \\
\hline & & Tawangrejeni & 303,381 & 0 & 0,034 & 255,351 & 0 & 47,997 \\
\hline & & Tanggung & 491,155 & 0 & 0 & 125,998 & 0 & 365,157 \\
\hline & & Tumpakrenteng & 647,514 & 0 & 0 & 0 & 263,728 & 383,786 \\
\hline & & Turen & 297,260 & 0 & 0 & 0 & 0 & 297,260 \\
\hline & & Undaan & 218,209 & 0 & 0 & 216,022 & 0 & 2,187 \\
\hline & & TOTAL & 8320,297 & 124,999 & 636,041 & 4003,380 & 855,253 & 2700,624 \\
\hline \multirow[t]{15}{*}{13} & \multirow[t]{15}{*}{ Wajak } & Bambang & 556,538 & 0 & 20,697 & 3,832 & 479,030 & 52,978 \\
\hline & & Blayu & 331,367 & 0 & 0 & 72,662 & 1,776 & 256,929 \\
\hline & & Bringin & 632,732 & 0 & 238,667 & 255,516 & 138,548 & 0 \\
\hline & & Codo & 463,641 & 0 & 0 & 338,379 & 96,366 & 28,896 \\
\hline & & Dadapan & 528,224 & 0 & 119,306 & 407,409 & 0 & 1,509 \\
\hline & & Hutan & 4269,852 & 9,543 & 40,086 & 393,124 & 2383,719 & 1443,379 \\
\hline & & Kidangbang & 608,811 & 0 & 0 & 0 & 231,286 & 377,525 \\
\hline & & Ngembal & 13,849 & 0 & 0 & 0 & 13,711 & 0,137 \\
\hline & & Patokpicis & 717,394 & 71,000 & 0,400 & 410,750 & 31,445 & 203,799 \\
\hline & & Sukolilo & 644,022 & 0 & 0 & 7,76833 & 258,021 & 378,232 \\
\hline & & Sumberputih & 913,019 & 100,479 & 37,267 & 378,598 & 266,741 & 129,935 \\
\hline & & Sukoanyar & 266,011 & 0 & 0 & 0 & 167,561 & 98,450 \\
\hline & & Wajak & 846,594 & 0 & 0 & 0,147 & 37,442 & 809,005 \\
\hline & & Wonoayu & 123,216 & 23,977 & 0 & 0 & 99,239 & 0 \\
\hline & & TOTAL & 10915,267 & 204,999 & 456,423 & 2268,185 & 4204,885 & 3780,775 \\
\hline
\end{tabular}

Sumber : Hasil Analisa dan Perhitungan 

Keterangan :
$\mathrm{S} \quad=$ Sedang
SR = Sangat Ringan
$\mathrm{B}=$ Berat
$\mathrm{R} \quad=$ Ringan
$\mathrm{SB}=$ Sangat Berat

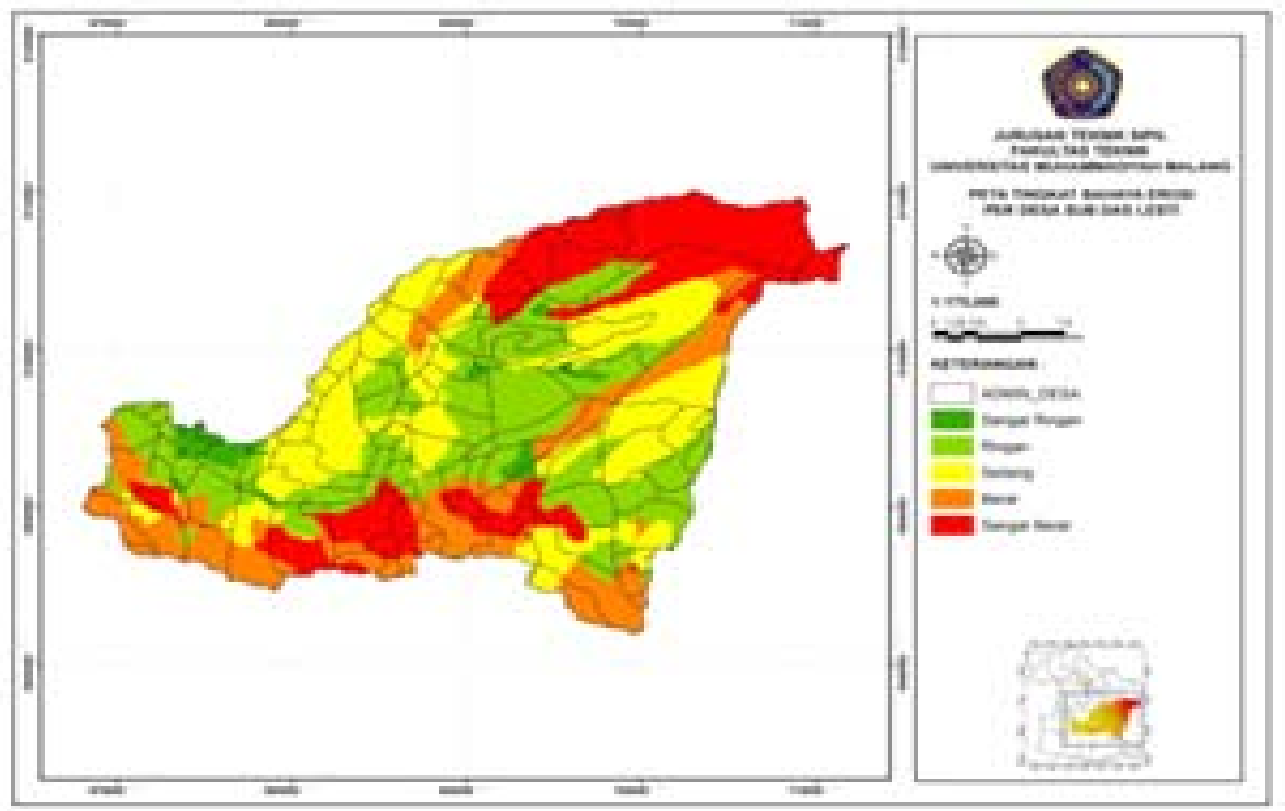

Gambar 5. Peta Tingkat Bahaya Erosi Per Desa

\section{KESIMPULAN DAN SARAN}

\section{Kesimpulan}

1. Nilai total erosi sebesar $6.551 .087,516$ Ton/ Tahun, setelah dibagi dengan luas lahan seluas 61.941,204 Ha, maka diperoleh laju erosi sebesar 105,763 Ton/Ha/Tahun, sehingga tebal tanah yang hilang atau yang tererosi sebesar 166,587 $\mathrm{mm} /$ Tahun.

2. Tingkat bahaya erosi pada Sub DAS Lesti untuk kategori Berat mencapai $(31,421 \%)$ dari luas wilayah, kategori Sedang $(24,146 \%)$, kategori Ringan (22,151 \%), Sangat Berat (16,123\%), dan Sangat Ringan $(6,159 \%)$.

3. Laju erosi terbesar pada Sub DAS 1 sebesar 565,536 ton/ha/thn, dengan luas area 2249 ha. Erosi tanah yang dihasilkan sebesar 1.271.889,511 ton/tahun, dan mengakibatkan tanah yang tererosi sebesar $21,341 \mathrm{~mm} /$ Tahun, pada solum tanah kateogri sedang $(30-60 \mathrm{~cm})$ dan solum tanah kategori dalam $(>90 \mathrm{~cm})$, sehingga masuk dalam kategori Sangat Berat. Sedangkan untuk laju erosi terendah terdapat pada Sub-Sub DAS 49 yaitu sebesar 1,447 ton/ ha/thn, tebal tanah yang hilang atau tererosi sebesar 0,055 mm/Tahun, dengan luas lahan 46,00 ha, dengan tanah kategori dalam $>90 \mathrm{~cm}$, masuk dalam kondisi Sangat Ringan.

\section{Saran}

1. Laju erosi perlu untuk diturunkan dan dikendalikan maka dengan melakukan tindakan rehabilitasi lahan dan konservasi tanah dengan mengkombinasikan metode vegetatif dan mekanik sesuai dengan ketentuan dan persyaratan yang secara ekonomi dan teknis dapat diterapkan serta diterima masyarakat setempat.

2. Perlu juga dilakukan tindakan rekayasa sungai (seperti pembangunan bangunan pengendali sedimen di sungai) guna mengurangi erosi dan sedimentasi yang menuju hilir.

3. Agar studi ini dapat diterapkan di lapangan, maka perlu adanya kajian lanjutan mengenai kondisi kekritisan lahan, klasifikasi kemampuan lahan, Arahan Rehabilitasi Lahan dan Konservasi Tanah (ARLKT), dan budaya masyarakat. 


\section{DAFTAR PUSTAKA}

Asdak, C. 2002. Hidrologi dan Pengelolaan Daerah Aliran Sungai. Yogyakarta. Gadjah Mada University Press.

Hardjowigeno, S. 2003. Ilmu Tanah. Jakarta: CV Akademika.

Prahasta Eddy, 2002. Sistem Informasi Geografis: Tutorial ArcView. Bandung: CV. Informatika.

Prahasta Eddy, 2005. Konsep-Konsep Dasar Sistem Informasi Geografis. Bandung : CV. Informatika.

Riduwan, 2008. Dasar-Dasar Statistika. Bandung :Alfabeta

Utomo, WH, 1994. Erosi dan Konservasi Tanah. IKIP Mala 